\title{
Culture Convergence of Manufacturing Managers in Mexico, Korea, Hong Kong, and USA
}

\author{
Maria A. Leach-Lópeza ${ }^{\star}$, Megan M. Leach ${ }^{b}$ Eunsuh Leec \\ a School of Accountancy, University of Southern Mississippi, United States of America, maria.leach@usm.edu \\ ${ }^{b}$ School of Accountancy, University of Southern Mississippi, United States of America, megan.leach@usm.edu \\ cDepartment of Accounting, Gyeongsang National University, BERI, Republic of Korea, eslee88@gnu.ac.kr \\ ${ }^{*}$ Corresponding author.
}

Received: 15 February 2019, revised: 7 May 2019, accepted: 17 June 2019, published: 17 June 2019

\begin{abstract}
This study evaluates cultural values of mid-level managers working in manufacturing firms located in four countries to attempt to detect purposeful movements towards cultural value convergence, if any. Using Hofstede's VSM94 questionnaire, the cultural values of managers and non-managers located in Mexico, Korea, Hong Kong, and the United States of America (USA) were calculated. These values were evaluated using Ttests, ANOVA, and Wilcoxon tests, and were graphed to illustrate the movement and convergence path of the cultural values. A trend toward convergence of cultural values among mid-level managers in four countries was detected. Survey design used mid-level manufacturing managers in four different countries. The study contributes to cross-cultural studies by triangulating results with non-managers and using large and small firms. This study suffers from common limitations encountered when using a questionnaire to gather data, including the sample sizes and respondents' demographics. Despite limitations, results add to this literature stream to assist future researchers in hypothesis development. The results indicate a purposeful shift in cultural values of manufacturing mid-level managers. Findings should encourage multinational firms to set up global Management Control Systems (MCS) for an efficient and effective use of resources. Samples from neglected locations were gathered, detecting convergence, suggesting that effective management may be independent from national culture, and thus be about developing best practices throughout the global organization.
\end{abstract}

Keywords: International Accounting; Cultural Values; Management Control Systems; Convergence; Hofstede; Culture Convergence.

JEL codes: M1, M14, M16, M48, M53, M54.

\section{INTRODUCTION}

The business world has become more global over the past few decades, but the breadth of this globalization is still under scrutiny (Rugman \& Verbeke, 2004; Verbeke \& Asmussen, 2016). Today's global managers face a more dynamic, complex, competitive, and uncertain environment than ever before. Challenges are presented by the cultural, political, economic, and legal aspects of multinational business environments (Thomas, 2008). However, cultural values are still considered uniquely important to global managers for several reasons. First, the political, economic, and legal characteristics of a country are a manifestation of culture (Thomas, 2008). Culture influences the way organizations operate, the goals people set in society, and the contributions people provide to behaviours and policies (Schwartz, 1992). Second, culture is mostly invisible (Thomas, 2008). The influence of culture is difficult to detect, so that managers often overlook it. Although culture may or may not be the most important influence on the practice of management, cultural aspects are often neglected by managers. Finally, the practice of management is largely dependent on interpersonal interactions. A distinct characteristic of global management is that these interactions occur among people with different cultural backgrounds. A global management perspective where management refers to what managers do, rather than what functions they serve, emphasizes the importance of interpersonal interactions across cultures (Thomas, 2008). 
According to Taras, Steel \& Kirkman (2012), the concept of culture used by most researchers is based on Hofstede's work (1980). Kirkman, Lowe \& Gibson (2017) find that the Hofstede's cultural value dimensions continue to thrive in management research. Hofstede developed a commonly accepted terminology to identify and describe cultures. Culture became an important construct in that it indicates, in general, how a person behaves in a certain role or status, in a society, or how a person responds to a situation within that society (Harrison, 1993). The concept of "culture" cannot be expressed in a single, all-encompassing definition. ${ }^{1}$ It has been defined as "the total way of life of a people; the social legacy the individual acquires from his (her) group; a way of thinking, feeling, and believing; a storehouse of pooled learning; learned behaviour ... Culture is to a human collectivity what personality is to an individual (Perera \& Mathews, 1990, p. 221)."

Hofstede (2015) defines culture as "an evolved capacity for adaptation at group level" (p.548). He argues that management systems in the $21^{\text {st }}$ Century will not be distinctively different from management systems in the $20^{\text {th }}$ Century (Hofstede, 1999; 2001) and expects that the development of management theories will become more adapted to national culture systems in different parts of the world. The unique trait of management and management systems is that they are always about people (Dunk, 2001). Therefore, effective management might be dependent on cultural values (Harrison \& McKinnon, 1999; Green, 2012; Leach-López, 2013). Hofstede's (1999) viewpoint is that management problems will remain the same over time, but managerial solutions will differ from country to country. ${ }^{2}$ Because of differences in cultural values, Hofstede believes that organizations aspiring to be global must be cautious when applying the latest management fad (Hofstede, 1999).

Kirkman et al. (2017) contend that "Culture cannot be assumed to be static" (p. 20). In recent years, the theory and research on socioeconomic development have led to an expected convergence of cultural values because of modernization driven by overpowering political and economic forces (Carr \& Pudelko, 2006; Munusamy, Valdez, Lo, Budde-Sung, Suarez \& Doktor, 2009). Convergence of cultural values implies that the commonalities of business ideologies might be driving similarities in thought and value formation (Harpaz, 1990; Schwind \& Peterson, 1985; Gentry \& Sparks, 2012).

Hofstede (2001) argues that cultural change would be extremely slow and should be measured in terms of generations and centuries, not decades. He also argues that individual culture values which are developed in early childhood would not be changed throughout one's life (Hofstede, Neuijen, Ohayv \& Sanders, 1990). The current study investigates whether cultural values of mid-level managers in manufacturing firms might be evolving towards adaptation of a more global cultural value in multinational corporations. Using Hofstede's measurement, the cultural values of samples obtained in four countries are compared to the cultural values reported by Hofstede (2001). If cultural change is extremely slow, as argued by Hofstede (2001), then no movement of the cultural values of the countries sampled would be observed.

In this study, we detect movement of cultural values among mid-level managers in four different countries. A surprising find was the way in which societies handle the problem of accepting hierarchical order and human inequalities (Power Distance as labelled by Hofstede, 1980). Power Distance shows signs of convergence, regardless of education and country. In addition, we find that the cultural values in Mexico, the Republic of Korea, and Hong Kong are closer to those of the United States of America (USA).

This paper is organized as follows. Section two explains the selection of the four countries sampled. Section three includes a review of relevant literature. Sections four and five include the research question and the research study design. Data analysis is presented in section six. Research implications of this study's results related to management control systems are presented in section seven. The conclusion and limitations are included in the last section.

\footnotetext{
1 The definition of culture can be unclear. For example, Anthropologists Kroeber \& Kluckhohn (1952) identified more than 160 different definitions of the term culture.

2 According to Hofstede (1984), "The nature of management skills is such that they are culturally specific: a management technique or philosophy that is appropriate in one national culture is not necessarily appropriate in another (p.81)."
} 


\section{SAMPLED COUNTRIES}

This study uses Hofstede's cultural questionnaire to measure the cultural values of managers and nonmanagers located in four global locations: Mexico, Republic of Korea (hereafter, Korea), Hong Kong, and the USA. Including USA in this study is based on this country's great economic power. Mexico, Korea, and Hong Kong have close relationships with USA. Additionally, current geopolitical events have highlighted the economic ties between USA and Mexico, Korea, and China, and the trading challenges that exist between USA and the other three countries.

The impetus for this study was the geographic nearness of Mexico to USA. The relations between these two countries are broad and go beyond diplomatic and official relations. They include extensive commercial, cultural, and educational ties. These two countries have a 1.4 billion-dollar trade and have hundreds of thousands of legal border-crossings each day. About a million USA citizens live in Mexico. USA tourists to Mexico numbered over 20 million in 2013, making Mexico the top traveling destination for USA travellers. Mexican tourism to the USA was over 14 million in 2013, spending an estimated $\$ 10.5$ billion (United States Department of State, 2016a). Additionally, the NAFTA agreement allowed USA multinational firms to have manufacturing firms in Mexico. This relationship will very likely strengthen with the new USMCA ${ }^{3}$ agreement. With all this movement and transference, might Mexico's cultural values have changed? This question matters because Hofstede's cultural values are widely used for theory development including management control systems research.

USA multinationals are also located in Korea and Hong Kong. These two locations are not geographically close to USA but, like Mexico, they are economically close to USA. Thus, Korea and Hong Kong were also included in this study to determine whether economic ties are creating dynamic cultural values in the four countries studied.

USA and Korea have a close trading relationship. In 2015, the trade between these two countries totalled $\$ 50$ billion, making Korea USA's seventh largest trading partner. In 2015, USA was Korea's second largest trading partner, second largest export market, and third largest source of imports (United States Department of State, 2016b). USA has experienced a trade deficit with Korea since 1998. The total deficit for 2017 was $\$ 22.9$ million and $\$ 27.6$ million in $2016 .{ }^{4}$

Hong Kong's trade deficit increased by HKD 14.4 billion from December 2016 to HKD 59.9 billion in December of 2017, with an HKD 53.1 trade deficit with the United States. The increase was due to higher purchases of electrical machinery, petroleum, and petroleum products. ${ }^{5}$ USA remains one of the largest sources of foreign direct investment in Hong Kong. There are about 1,400 USA firms and 85,000 American residents in Hong Kong (United States Department of State, 2016c).

\section{LITERATURE REVIEW}

\subsection{Hofstede's cultural values}

Hofstede (1980) identified, and labelled, four dimensions of culture: large versus small power distance, individualism versus collectivism, masculinity versus femininity ${ }^{6}$, and strong versus weak uncertainty avoidance. Hofstede \& Bond (1988) added a fifth cultural value: long-term orientation. ${ }^{7}$

According to Minkov \& Hofstede (2011), Power Distance (PDI) is defined as "social inequality, including the relationship with authority (p.12)." Societies classified as large PDI are characterized by the acceptance of inequality; people tend to accept a hierarchical order in which everybody has a place, which needs no further justification (Perera \& Mathews, 1990). Higher PDI scores imply that subordinate consultation may not be as important as in a small PDI society because there is a tendency for its members to accept paternalistic management (Perera \& Mathews, 1990; Stammerjohan, Leach-López \& Stammerjohan, 2015).

\footnotetext{
3 United States-Mexico-Canada trade agreement.

4 https://www.census.gov/foreign-trade/balance/c5800.html

5 https://tradingeconomics.com/hong-kong/balance-of-trade

${ }^{6}$ Some readers might find the terms "masculine" and "feminine" offensive. Hofstede used these labels and they should not be viewed as stereotypes, but merely as what they are, labels. The purpose of this paper is to encourage future researchers to measure cultural values of participants and not to introduce and substitute labels that have been widely used.

7 This last cultural dimension is also called Confucian dynamism, which is perhaps a misleading label (Devine, O'Clock \& Rooney, 2000).
} 
Individualism (IND) versus collectivism is based on the relationship between one individual and other individuals in society. In a high individualistic society, or culture, people focus on themselves as individuals rather than on the group, or groups, to which they may belong. Under this perspective, an individual is seen as having an identity in and of him or herself, which is separable from, and is not dependent upon, a group affiliation (Hofstede, 1980). Under a collectivistic society, it is the group, and not the individual, that is seen as the basic unit of survival (Hui, 1984). By comparing Chinese participants and Anglo participants, Salter \& Schulz (2005) find that collectivism plays a significant role in the willingness to share information.

Masculinity (MAS), at one end, represents a societal preference for showing off, for achievement, and assertiveness, for making money or enjoying material success. At the other end, femininity represents a preference for putting relationships with people before money, helping others, and caring for the weaker. This dimension draws attention to the existence within society of competitiveness as opposed to cohesion, equity as opposed to equality, and achievement motivation as opposed to relationship motivation.

Uncertainty avoidance (UAI) relates to the degree to which members of a society feel uncomfortable with uncertainty and ambiguity. A strong UAI society is one in which there is low tolerance for ambiguity and uncertainty and an aversion towards risk taking (Hofstede, 1980). A strong UAl society believes that decisions should be left to experts. There is an obvious mutual distrust among citizens and authorities. Members of a strong UAI society consider themselves incompetent and authorities consider them incompetent (Hofstede, 1999).

Lastly, long-term orientation (LTO) refers to a society fostering virtues oriented towards future rewards, particularly perseverance and thrift, observation of status, and saving "face." Short-term orientation (STO) stands for a society focused on the past and the present, instead of on the future, with a preference for immediate rewards (Hofstede \& Bond, 1988). This cultural value may capture differences in value preferences between Western and Eastern cultures, with Western cultures usually exhibiting STO and Eastern cultures exhibiting LTO (Devine et al., 2000). Specifically, Wang \& Hunton (2011) find that participants from USA, who indicated a relatively short-term time orientation, are more effective when they participate in a short-term planning horizon than a long-term planning horizon.

\subsection{Convergence-Divergence theory}

Convergence-divergence is based on the Institutional theory. According to Westney (1997), the Institutional theory focuses on the ways that organizations in shared environments come to adopt structures that are viewed as appropriate and that are reinforced in interactions with other organizations. Fundamentally, Institutional theory suggests that organizational structures are influenced by two factors. The first consists of environmental agents shaping the organizations. The second is the firm's internal process that interprets certain external validated structures as appropriate. Regardless of the source of the institutional pressures, the effects are twofold: first, institutionalized activities are resistant to change (divergence) and second, organizations in such institutionalized environments are pressured to become similar (convergence).

Proponents of the divergence approach argue that national culture, not economic ideology develops cultural values (Ricks, Toyne \& Martinez, 1990). Thus, even though a country adopts capitalism, the cultural values of those in the workforce will remain unchanged (Lincoln, Olson \& Hanada, 1978). According to DiMaggio (1983) and Berger \& Heath (2008), cultural divergence occurs because individuals want to be different from members of other social cultural groups. People want to be viewed as unique and different from others who might initially appear very similar (Tajfel, 1982). Overall, the divergence approach suggests that individuals retain their own diversity, which includes culturally determined values, regardless of economic ideology (Evans, 1970; Cole, 1973).

Proponents of the convergence perspective suggest that common economic orientation drives modernization (Eisenhartdt, 1973) and eventually leads to a common society where differences in cultural values cease to exist (Kerr, Dunlop, Harbison \& Myers, 1960). In other words, given enough time, the cultural values in different countries will reach a point where no significant differences in values, attitudes, beliefs, and behaviours might exist (Weed, 1979). This theory of convergence social evolution starts with the presumption that the industrialization process is desirable because it allows for the elimination of poverty, the search for a better life, the choice of occupation, etc. (Webber, 1969). The key argument of the convergence perspective is that convergence places more emphasis on the common requirements of management, than on the importance of cultural differences (Rowley \& Benson, 2002).

Convergence theory claims that because of technological advancement, global communication, travel and tourism, collaboration between organizations and nations, increasing immigration and cross-national and ethnic 
marriages, societies are becoming more homogenized and, as a result, the world's cultures are converging to commonality (De Mooij, 2004). Consumers increasingly demand and consume similar products throughout the world; they eat the same food, wear the same brands of clothing, and watch the same TV programs (De Mooij, 2004). As consumers become more similar and share similar attitudes and behaviours, a cultural convergence takes place. Globalization can significantly accelerate cultural homogenization and convergence toward a common set of cultural traits and practices. According to McLeod (2004), the process of cultural convergence is strengthening by the rise of internet use and information technology which help disseminate Western values around the world.

However, there are several reasons for the possibility of convergence to be low. According to Salamon (1997), there are limiters on convergence that would include different stages of industrial and economic development, distinctive political-economic frameworks, different levels of organizational flexibility, different choices at society and organization levels on the nature, content, and process of employment relationship, divergence between stated institutional frameworks, variation in operations of technology, and alternative solutions to common problems.

\section{RESEARCH QUESTION}

It is assumed that culture is unchangeable (Ricks et al., 1990). Hofstede stressed that cultural change would be extremely slow. He predicted that national culture scores would not change substantially "until at least 2100 " (Hofstede, 2001, p. 36). Hofstede viewed theories of cultural change as "naïve" (Hofstede, 2001, p. 34).

Thanks to electronic communications, the size of the business world is shrinking (Norris \& Inglehart, 2009). Communications occur instantaneously across continents and time zones. It is conceivable that all this 'nearness' might influence the cultural values of all those involved in the global value chain. A sense of cultural convergence has been alluded to by recent researchers (Vanhala, Kaarelson \& Alas, 2006; Carr \& Pudelko, 2006; Inglehart \& Baker, 2000; Munusamy et al., 2009). Inglehart (2008) also detects a cultural convergence during the 36-year period of his study.

Given the widespread use of Hofstede's cultural values, ${ }^{8}$ it appears that these cultural values are still useful in hypotheses and theory development. Our research question asks whether Hofstede's claim of static cultural values will be observed. Based on the Institutional theory, and the geographic and economic proximity of the four countries sampled, a priori, some movement in the cultural values of our samples is expected. Given the strong economic leadership of USA's multinationals, a convergence of cultural values towards USA's would be logical. But it is also possible that USA's cultural values might be moving towards some common mid-point.

\section{RESEARCH DESIGN}

\subsection{Data collection}

Hofstede's VSM 94 questionnaire was used to measure cultural values of samples in four countries. The questionnaire was applied to samples in Mexico, Korea, Hong Kong, and USA. The VSM 94 is designed for measuring culture-determined differences between samples of respondents from different countries or regions. It consists of 20 content questions and 6 demographic questions. The 20 content questions address the five different dimensions of national culture with four questions each. The cultural values obtained range from zero to 100 . Using the same version of the VSM and having a range of zero to 100 aids in the cultural values comparison.

Hofstede's VSM 94 is copyrighted by Geert Hofstede and freely available for research purposes (Hofstede, 2001). A copy of the questionnaire written in English and Spanish are available along with the manual needed to calculate the cultural values. The questionnaires used in Hong Kong and Korea were translated from English by two independent translators and compared for possible differences.

The VSM 94 was administered to eight distinct groups. One group from the United States, three separate groups from Mexico, three groups from Korea, and one group from Hong Kong. Within each country there was at least one respondent group composed of mid-level managers working in manufacturing firms in each country. USA's and Hong Kong's respondents were all managers working in manufacturing. There were two groups of managers in Mexico and two groups of managers in Korea. One group of respondents in Mexico were 'people

8 The popularity of Hofstede's cultural values does not seem to have abated. For example, in the Journal of International Business Studies alone, Rapp, Bernardi \& Bosco (2011) identified 118 articles that used Hofstede's uncertainty avoidance value for various purposes, such as validation of research results. 
on the street' selected using a convenience random request. One group of respondents in Korea was composed of undergraduate university students.

The human resource $(\mathrm{HR})$ departments of 27 manufacturing firms located in south eastern USA were contacted to get permission to apply the questionnaire in their respective firms. The various USA firms were provided an e-mailed copy of the questionnaire with instructions to electronically distribute the questionnaire to the manufacturing managers. The responses were returned directly to the authors as an email attachment.

The first Mexican sample was of Mexican managers working for manufacturing firms located on the USAMexico border that have a USA firm as a parent corporation (Mexico-border sample). A list of the maquiladoras located in Nuevo Laredo was obtained from Mexico's Department of Commerce. Maquiladoras are factories that import materials or parts into Mexico to make goods for re-export. The list included 39 active companies. The human resource departments of the listed maquiladoras were contacted. Copies of the questionnaire translated into Spanish were hand delivered to various firms that agreed to cooperate. The companies who received questionnaires were visited again after a few days to collect whatever questionnaires had been completed.

The second sample from Mexico varies from the sample described in the paragraph above by the geographic location only. This second Mexican sample was obtained in Puebla, a metropolitan city located about 250 miles south of Mexico City (Mexico-interior sample). The list of maquiladoras located in Puebla included 49 active listings.

The third sample from Mexico was obtained in Mexico City and Puebla. This sample consisted of individuals met randomly throughout both cities (Mexico-street sample). The researchers chose areas where people congregate such as shopping areas, downtown, airports, subway stations, large family gatherings, restaurants, etc. The three samples obtained in Mexico were combined into one grand sample for the country (Mexico-all sample).

The first Korean sample obtained consisted of Korean managers working for manufacturing firms located throughout Korea that have a USA firm as a parent corporation (Korean managers-USA firms sample). A list of 80 companies was found at the Annual Corporation Reports published by the Korean Economic Newspaper. The questionnaires were sent to the manager of each firm through the mail. The managers returned the responses through the mail.

The second Korean sample consisted of Korean managers working for firms located throughout Korea owned by Korean companies or jointly with Japanese companies (Korean managers-non-USA sample). These managers who agreed to answer the questionnaire were acquaintances of one of the researchers.

The third Korean sample consisted of Korean university students located in Korea. All students were taking Accounting Principle class and were fluent in both spoken and written English. The three samples obtained in Korea were combined into one grand sample for the country (Korea-all sample).

The Hong Kong sample was gathered at a single car parts manufacturing firm. The questionnaires were hand delivered and hand collected. This manufacturing firm is a joint venture with a USA car manufacturing firm.

\subsection{Cultural values}

The cultural values of all respondents from each country were calculated, as well as the cultural values of the six samples described in the prior section. The combined cultural values of the three Mexican samples (Mexicoall sample), and the combined cultural values of the three Korean samples (Korea-all sample) were calculated.

The VSM 94 includes a demographic question asking respondents about the type of work they do. The choices are: (1) no paid job (including students), (2) unskilled or semi-skilled manual worker, (3) office worker or secretary, (4) vocationally trained craftsperson, technician, informatician, nurse, artist or equivalent, (5) academically trained professional or equivalent (but not manager of people), (6) manager of one or more subordinates (non-managers), and (7) manager of one or more managers. Using the answers to this question, the managers in the Mexico-street sample (choices 6 and 7) were isolated (Mexican managers-street sample) and their cultural values were calculated. It can be argued that the respondents who classified themselves as (5) academically trained professional are the managers of the future. Based on this logic, a subset of respondents choosing answers (5) (6) and (7) was isolated (Mexican managers/college-street sample) and their cultural values were calculated. The third subset of the Mexico-street sample included all respondents who selected answers (1) through (5), so this subset did not include managers (Mexico-street no managers sample). 
To evaluate whether cultural values of samples drawn from a single country may vary from sample to sample, five sub-samples from the three Mexican samples were formed. The five sub-samples were as follows: (1) Mexican managers-USA firms; (2) Mexican managers-street; (3) Mexican managers/college-street; (4) Mexicostreet no managers; and (5) Mexican managers-all. Sub-sample 1 consisted of the Mexico-border and the Mexico-interior samples (Mexican managers-USA firms). This sub-sample allowed for analysis of cultural values of Mexican managers with business ties to the United States. The managers from the Mexico-street sample were added to sub-sample 1 to obtain cultural values for all managers in the study (Mexican managersall).

Hofstede (1980) suggests that gender, age, and education could influence cultural values. Subgroups in these three categories were isolated from the total sample for each country to evaluate the importance of these three variables and to serve as an aid for future researchers. For the USA sample, cultural values were calculated for the following three groups: males, respondents aged 40 to 59 years old, and respondents with attended college. For the Mexican sample (Mexico-all), cultural values were calculated for the following eight groups: males and females; respondents aged 25 to 34 years old, 35 to 39 years old, and 40 to 59 years old; and respondents who attended high school, respondents who attended college, and respondents who had postgraduate studies. The selection of these groups was based on the number of respondents in each group. The VSM 94 Manual indicates that the minimum number to include in a sample of respondents is 20 . When the number of respondents is less than 20 , the influence of single individuals becomes too strong.

\section{DATA ANALYSIS}

\subsection{Demographic data}

Table 1 presents demographic data for the total combined sample for each country. The samples are dominated by males. The Mexican sample has an unexpected representation of females at $37 \%$. Of the four countries, the USA respondents are oldest, on average. The predominant age range for the USA is between 40 and 59 years old. Most of the Korean sample report an age of 24 years or less due to a large number of Korean students in the sample (78 out 155). The respondents from Mexico and Hong Kong tend to be younger, but there is reasonable spread in the age categories. Overall, the lowest educational level was reported by the Mexican respondents.

\begin{tabular}{|c|c|c|c|c|c|c|c|c|}
\hline \multirow[b]{2}{*}{ Respondents: } & \multicolumn{2}{|c|}{ Hong Kong } & \multicolumn{2}{|c|}{ Korea } & \multicolumn{2}{|c|}{ Mexico } & \multicolumn{2}{|c|}{ USA } \\
\hline & $\frac{\text { Total }}{50}$ & $\frac{\%}{100}$ & $\frac{\text { Total }}{155}$ & $\frac{\%}{100}$ & $\frac{\text { Total }}{167}$ & 100 & $\frac{\text { Total }}{54}$ & $\frac{\%}{100}$ \\
\hline \multicolumn{9}{|l|}{ Gender: } \\
\hline Male & 25 & 50 & 124 & 80 & 103 & 62 & 46 & 85 \\
\hline Female & 12 & 24 & 31 & 20 & 61 & 37 & 6 & 11 \\
\hline No response & 13 & 26 & 0 & 0 & 3 & 2 & 2 & 4 \\
\hline \multicolumn{9}{|l|}{ Age: } \\
\hline 24 or less & 4 & 8 & 78 & 50 & 20 & 12 & 0 & 0 \\
\hline $25-29$ & 12 & 24 & 8 & 5 & 34 & 20 & 5 & 9 \\
\hline $30-34$ & 9 & 18 & 8 & 5 & 23 & 14 & 3 & 6 \\
\hline $35-39$ & 8 & 16 & 25 & 16 & 25 & 15 & 7 & 13 \\
\hline $40-49$ & 8 & 16 & 33 & 21 & 43 & 26 & 14 & 26 \\
\hline $50-59$ & 5 & 10 & 3 & 2 & 17 & 10 & 14 & 26 \\
\hline $60+$ & 0 & 0 & 0 & 0 & 2 & 1 & 3 & 6 \\
\hline No response & 4 & 8 & 0 & 0 & 3 & 2 & 8 & 15 \\
\hline \multicolumn{9}{|l|}{ Education: } \\
\hline Up to 9th grade & 2 & 4 & 11 & 7 & 12 & 7 & 0 & 0 \\
\hline 10th to 12 th & 0 & 0 & 36 & 23 & 25 & 15 & 3 & 6 \\
\hline Some college/degreed & 40 & 80 & 90 & 58 & 64 & 38 & 34 & 63 \\
\hline Post graduate & 4 & 8 & 18 & 12 & 59 & 35 & 13 & 24 \\
\hline No response & 4 & 8 & 0 & 0 & 7 & 4 & 4 & 7 \\
\hline
\end{tabular}




\subsection{Results}

Table 2 includes a comparison of the cultural values calculated by Hofstede (1980) for the four global areas under study and the cultural values for each sample and sub-sample within each global area. Other than the Uncertainty Avoidance index (UAI) the cultural values of the Hong Kong sample appear to have changed. Except for the Masculinity (MAS) cultural value, the cultural values of the Korean sample have also changed. The Mexican sample indicates that Power Distance (PDI) and Individualism (IND) have changed but MAS, UAI and Long-Term Orientation (LTO) have not changed. Even though the numerical values of the USA sample's cultural values are not exactly as those calculated by Hofstede (1980), the USA sample classification in each of the cultural values mirror those calculated by Hofstede (1980).

Given that the USA cultural values appear to be steady, a logical step is to compare the other three regions' current cultural values with those of the USA sample. With the current samples, all four areas are now classified as having a small PDI and high IND. The USA and Mexico samples remain high MAS cultures and Korea remains a low MAS culture. The Hong Kong sample is classified as low MAS. Similar classification was detected in the UAI value of the USA, Hong Kong and Korean samples but Mexico remains strong on UAI. All four global regions are classified as low in LTO.

It is said that a picture is worth a thousand words. To this end, the cultural values of the four countries under study are depicted in Figure 1 tracing the movement of cultural values reported by Hofstede to those found in this study. Figure 2 illustrates the cultural paths for each country's mid-level managers. It is interesting to note that the movement in PDI, IND, and LTO appears to be purposeful towards some common point for the countries in total and for the mid-level managers within each country. The UAl appears to also be moving towards a common point but this movement is not as obvious as the movement observed in PDI, IND, and LTO. For the MAS value, there appears to be a bimodal movement with Mexico and USA remaining at a high MAS level and Hong Kong and Korea moving towards a common point in the low MAS sector. This convergence trend is consistent with the findings of Inglehart (2008). By comparing a wide range of values, norms, attitudes and beliefs in Belgium, Italy, France, Netherlands, West Germany, and the United Kingdom, measured from 1970 to 2006, he finds that the cultural differences between those six countries becomes less pronounced.

\begin{tabular}{|c|c|c|c|c|c|c|c|c|c|c|}
\hline \multirow[b]{2}{*}{ Hong Kong per Hofstede * } & \multicolumn{2}{|c|}{ PDI } & \multicolumn{2}{|c|}{ IND } & \multicolumn{2}{|c|}{ MAS } & \multicolumn{2}{|c|}{ UAI } & \multicolumn{2}{|c|}{ LTO } \\
\hline & 68 & Large & 25 & Low & 57 & High & 29 & Weak & 96 & High \\
\hline Hong Kong sample & 30 & small & 66 & high & 33 & low & 47 & weak & 47 & low \\
\hline South Korea per Hofstede * & 60 & Large & 18 & Low & 39 & Low & 85 & Strong & 75 & High \\
\hline Korea-all & 16 & small & 68 & high & 28 & low & 50 & weak & 30 & low \\
\hline Korean managers-US firms & 21 & small & 71 & high & 51 & $\mathrm{~h} / /^{\star \star}$ & 43 & weak & 31 & low \\
\hline Korean managers non-US firms & 21 & small & 66 & high & 61 & high & 51 & $s / w^{* *}$ & 31 & low \\
\hline Korean students & 12 & small & 66 & high & 7 & low & 55 & strong & 30 & low \\
\hline Mexico per Hofstede * & 81 & Large & 30 & Low & 69 & High & 82 & Strong & 82 & Low \\
\hline Mexico-all & 24 & small & 67 & high & 69 & high & 61 & strong & 50 & $\mathrm{I} / \mathrm{h}^{* *}$ \\
\hline Mexico-border & 29 & small & 72 & high & 83 & high & 48 & weak & 54 & high \\
\hline Mexico-interior & 31 & small & 48 & low & 85 & high & 77 & strong & 56 & high \\
\hline Mexico-street & 18 & small & 73 & high & 51 & $h / /^{* *}$ & 61 & strong & 44 & low \\
\hline Mexican managers-street & 24 & small & 68 & high & 18 & low & 55 & strong & 37 & low \\
\hline Mexico street-no managers & 16 & small & 74 & high & 58 & high & 63 & strong & 46 & low \\
\hline US per Hofstede * & 40 & Small & 91 & High & 62 & High & 46 & Weak & 29 & Low \\
\hline US sample & 31 & small & 95 & high & 70 & high & 33 & weak & 36 & low \\
\hline
\end{tabular}

ANOVA tests were used to calculate statistical differences in the cultural values of the four countries. As can be seen in Table 3, there were no statistical differences in the PDI values of the four countries. ${ }^{9}$ Full convergence is not detected in this study, but the trend appears to be towards convergence. The cultural values of the four

\footnotetext{
${ }^{9}$ When we conduct Wilcoxon test to check the robustness, results are similar to ANOVA test. There were not statistical differences in the PDI values of the four countries ( $p$-value $=0.2757)$, whereas there were statistical differences in IND, MAS, UAI, and LTO ( $p$-value $=0.0012, p$-value $=0.000, p$-value $=0.050$, and $p$-value $<0.001$, respectively $)$.
} 
countries are changing in what appears to be a tractable trend. This result is consistent with the finding of Inglehart (2008). He finds that cultural differences do not disappear completely, but cultural values of six different countries at almost all times moved in the same direction at a similar speed.

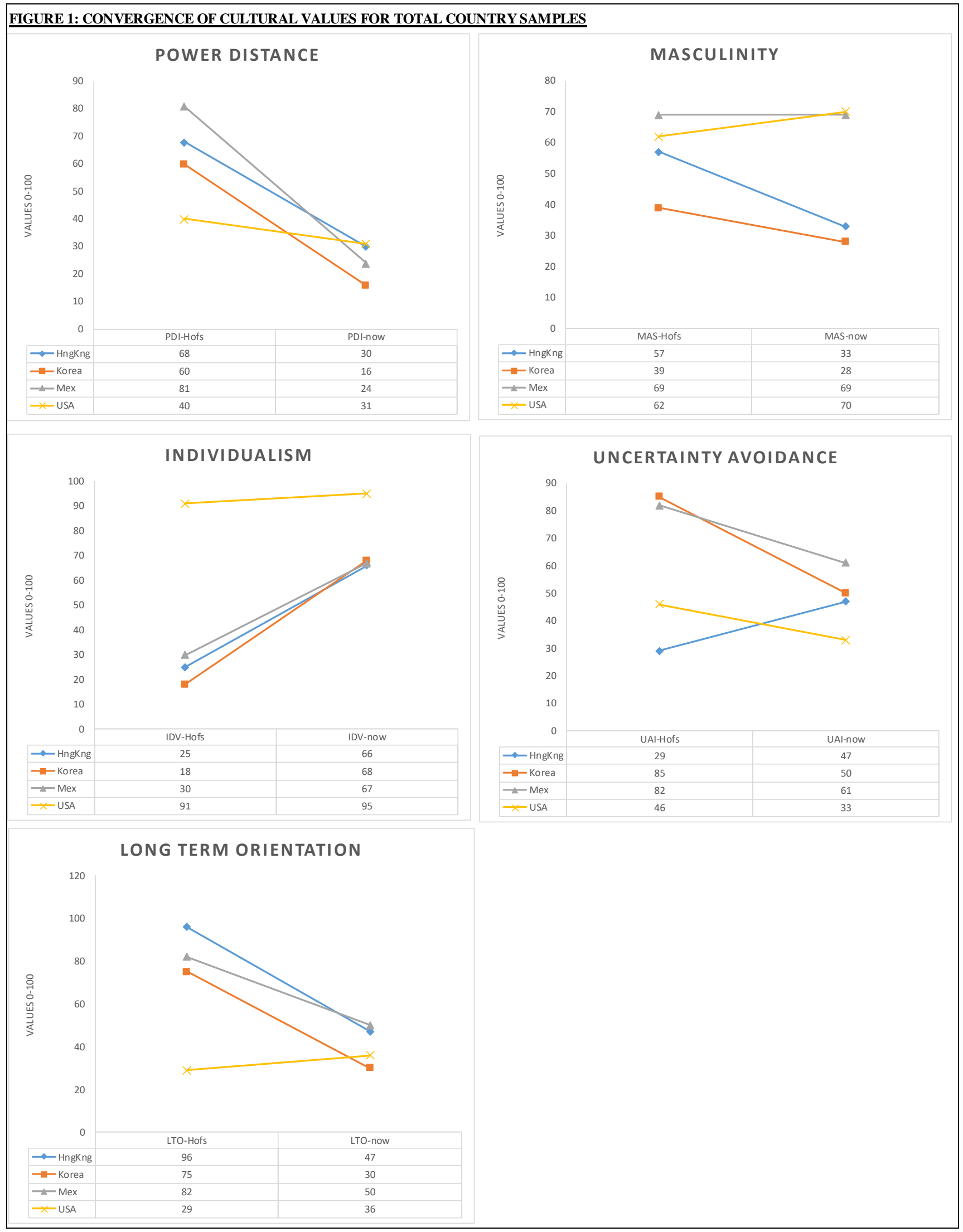




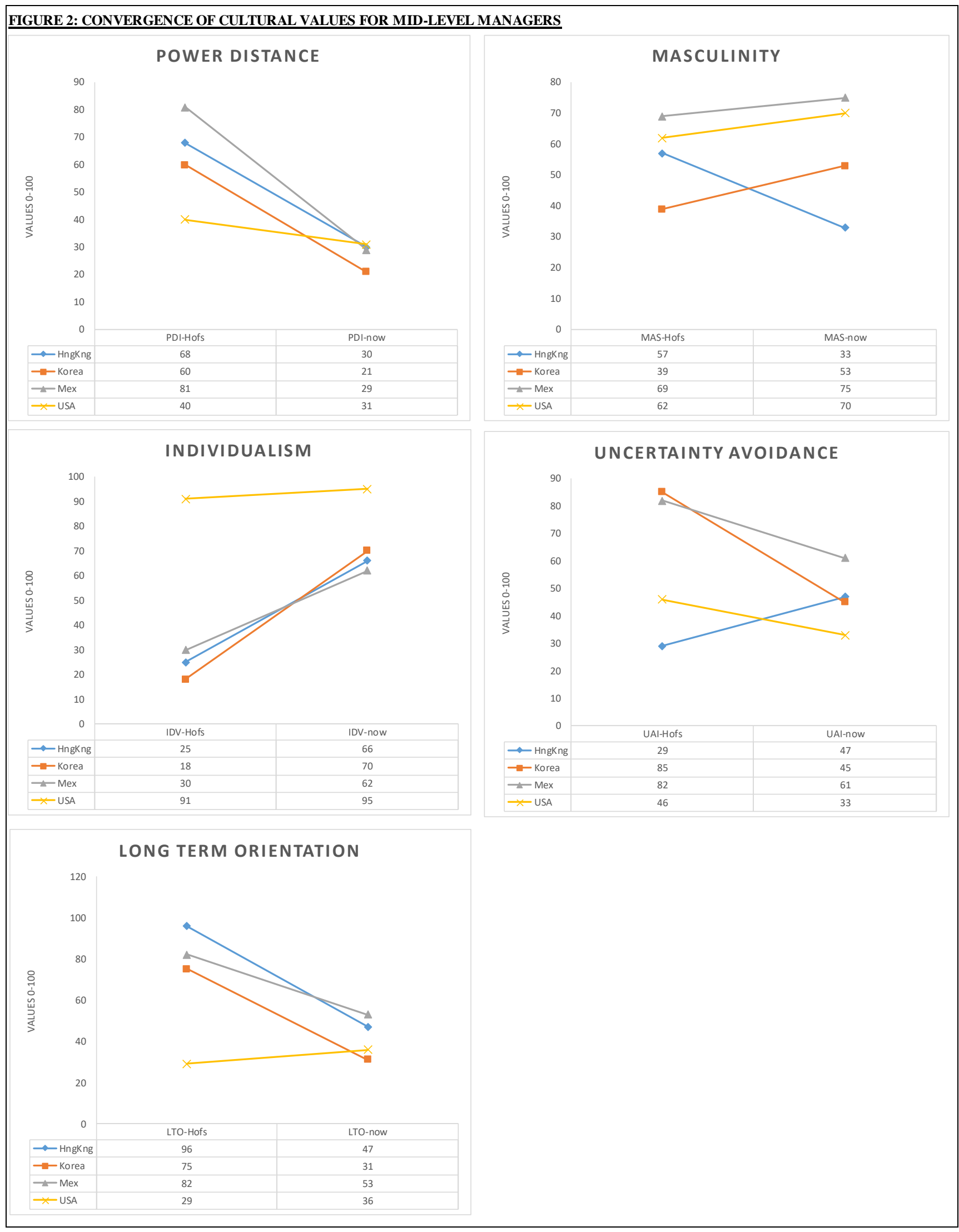

\subsection{Additional tests}

The results shown in Table 3 indicate that, statistically, all cultural values in Mexico, Korea, Hong Kong, and USA seem to be different, except for power distance (PDI). In this section, the cultural values of the sampled 
technology which drives cultural convergence. According to Munusamy et al., (2009), technology is a significant source of uniformity. As people from cultures are exposed to the common or one 'best way' technology, they too will become more alike. Development of communication can play a significant role in cultural convergence. Norris \& Inglehart (2009) find that cosmopolitan communication plays a significant role in convergence. ${ }^{12}$ Development of communication methods in Asian countries is rather dramatic. In the first quarter of 2015, the average Meta bit per second (Mbps) global standard was 5.0, whereas the value was 23.6 and 16.7 for Korea and Hong Kong, respectively. That is more than 3 times faster than global standards. Over $67 \%$ and more than 90 percent of the population in Korea has a cell phone and high-speed wireless internet, respectively. These high-speed communication developments may have helped Korea and Hong Kong converge with the USA.

Conducting more in-depth analysis, we divided the total sample from all four countries by education into high education (more than high school, $n=354$ ) and low education (high school or lower, $n=57$ ) and compared the cultural values. Untabulated results show that the cultural scores of these two groups are not statistically different. ${ }^{13}$

\begin{tabular}{|c|c|c|c|c|c|c|c|c|c|c|}
\hline \multicolumn{11}{|c|}{ ABLE 4: COMPARISONS OF } \\
\hline \multicolumn{11}{|c|}{ Table 4-A: Hong Kong versus USA } \\
\hline & \multicolumn{2}{|c|}{ PDI } & \multicolumn{2}{|c|}{ IND } & \multicolumn{2}{|c|}{ MAS } & \multicolumn{2}{|c|}{ UAI } & \multicolumn{2}{|c|}{ LTO } \\
\hline & $\begin{array}{c}\text { Sample } \\
\text { Size }\end{array}$ & Value & $\begin{array}{c}\text { Sample } \\
\text { Size }\end{array}$ & Value & $\begin{array}{c}\text { Sample } \\
\text { Size }\end{array}$ & Value & $\begin{array}{c}\text { Sample } \\
\text { Size }\end{array}$ & Value & $\begin{array}{c}\text { Sample } \\
\text { Size }\end{array}$ & Value \\
\hline Hong Kong & 50 & 31 & 50 & 81 & 50 & 36 & 50 & 51 & 50 & 47 \\
\hline US & 54 & 30 & 54 & 95 & 54 & 69 & 54 & 35 & 54 & 36 \\
\hline$f$-Value & \multicolumn{2}{|c|}{1.16} & \multicolumn{2}{|c|}{1.27} & \multicolumn{2}{|c|}{1.45} & \multicolumn{2}{|c|}{1.1} & \multirow{2}{*}{\multicolumn{2}{|c|}{$\begin{array}{c}1.36 \\
0.280\end{array}$}} \\
\hline$p$-value & \multicolumn{2}{|c|}{0.599} & \multicolumn{2}{|c|}{0.393} & \multicolumn{2}{|c|}{0.188} & \multicolumn{2}{|c|}{0.740} & & \\
\hline \multicolumn{11}{|c|}{ Table 4-B: Korea versus USA } \\
\hline & \multicolumn{2}{|c|}{ PDI } & \multicolumn{2}{|c|}{ IND } & \multicolumn{2}{|c|}{ MAS } & \multicolumn{2}{|c|}{ UAI } & \multicolumn{2}{|c|}{ LTO } \\
\hline & $\begin{array}{c}\text { Sample } \\
\text { Size }\end{array}$ & Value & $\begin{array}{c}\text { Sample } \\
\text { Size }\end{array}$ & Value & $\begin{array}{c}\text { Sample } \\
\text { Size }\end{array}$ & Value & $\begin{array}{c}\text { Sample } \\
\text { Size }\end{array}$ & Value & $\begin{array}{c}\text { Sample } \\
\text { Size }\end{array}$ & Value \\
\hline Korea & 155 & 16 & 155 & 68 & 155 & 28 & 155 & 50 & 155 & 30 \\
\hline US & 54 & 30 & 54 & 95 & 54 & 69 & 54 & 35 & 54 & 36 \\
\hline$f$-Value & \multicolumn{2}{|c|}{1.13} & \multicolumn{2}{|c|}{1.08} & \multicolumn{2}{|c|}{1.87} & \multirow{2}{*}{\multicolumn{2}{|c|}{$\begin{array}{c}1.35 \\
0.167\end{array}$}} & \multirow{2}{*}{\multicolumn{2}{|c|}{$\begin{array}{l}1.53 \\
0.074 \text { * }\end{array}$}} \\
\hline$p$-value & 0.5 & & 0.6 & & & $09^{* \star *}$ & & & & \\
\hline \multicolumn{11}{|c|}{ Table 4-C: Mexico versus USA } \\
\hline & \multicolumn{2}{|c|}{ PDI } & \multicolumn{2}{|c|}{ IND } & \multicolumn{2}{|c|}{ MAS } & $\mathrm{U}$ & & LT & \\
\hline & $\begin{array}{c}\text { Sample } \\
\text { Size }\end{array}$ & Value & $\begin{array}{c}\text { Sample } \\
\text { Size }\end{array}$ & Value & $\begin{array}{c}\text { Sample } \\
\text { Size }\end{array}$ & Value & $\begin{array}{c}\text { Sample } \\
\text { Size }\end{array}$ & Value & $\begin{array}{c}\text { Sample } \\
\text { Size }\end{array}$ & Value \\
\hline Mexico & 167 & 23 & 167 & 67 & 167 & 70 & 167 & 64 & 167 & 50 \\
\hline US & 54 & 30 & 54 & 95 & 54 & 69 & 54 & 35 & 54 & 36 \\
\hline$f$-Value & 1.0 & & 1.2 & & 1. & & 1.5 & & 1.2 & \\
\hline$p$-value & 0.8 & & 0.224 & & & $08^{* \star \star}$ & 0.2 & & 0.3 & \\
\hline dicat & 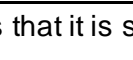 & istica & icant at & $21 \mathrm{I}$ & 10 level & specti & & & & \\
\hline TO is Lon & mive & on & & & & $\min$ & & & & \\
\hline
\end{tabular}

\section{IMPLICATIONS OF CULTURE AND MANAGEMENT CONTROL SYSTEMS}

Increased research has been directed at understanding the relationship between national culture and the design of management control systems (MCS). According to Harrison \& McKinnon (1999), cultural research of MCS has become more prominent because of two reasons. First is the importance of this research to the business community. More and more companies see globalization as an opportunity and a necessity to increase or maintain operations. The question then is whether these companies should transport their domestic MCS overseas, or whether they need to redesign the MCS according to the cultural imperatives of the overseas

12 According to Norris \& Inglehart (2009), cosmopolitan communication can be defined as the way that we learned about, and interact with, people and placed beyond the borders of our nation-state (p.3).

${ }^{13} \mathrm{p}$-values for PDI, IND, MAS, UAI, and LTO are $1.000,0.332,0.798,0.125$ and 0.565 , respectively. 
destinations. Second is the increased prominence of this type of research to the academic community (Harrison \& McKinnon, 1999; Green, 2012; Chung, Hsu \& Tsai, 2010; Dahlgaard, Pettersen \& Dahlgaard-Park, 2011). The design of MCS has been a major issue in accounting research for many years. Even though researchers have recognized the importance of culture, most of the MCS research has been conducted within single nations. Harrison \& McKinnon (1999) argue that the limited examination of the influence of culture on MCS model design has created under-specified models. Research examining the effect of culture on MCS design is relatively recent since it dates mainly from the 1980s.

It is evident that research of MCS in different countries is needed (Yazdifar \& Askarany, 2012; Hoque, 2014). From the literature, it is also evident that the academic community is rising to this challenge. Future researchers will have to go a step further when postulating hypotheses and examining their results. It is important that the cultural values of the sampled subjects be measured. Researchers may discover that similarities or differences in cultural values will indeed help them explain research results (Leach-López, Stammerjohan, Lee \& Stammerjohan, 2015). The examination of cultural values may indicate the need for MCS redesign or may indicate that multinationals can just transport their current systems from country to country in which they operate.

The topic of Management control systems (MCS) is very important to management accountants. ${ }^{14}$ It should also be an important topic for any multinational firm. Globalization has created many challenges when setting up a management control system for a multinational firm. Should a multinational firm set up MCS for each country? Should a multinational firm set up MCS for a group of countries? Or should a multinational firm simply set up MCS for the whole firm regardless of the global locations in which it operates? The first two options are costly and require additional computer resources, HR resources, training, monitoring, etc. If a multinational firm has different MCS throughout the organization, how can it equitably compare managers' performance from division to division, or from country to country? If research shows that cultural values of mid-level managers are very similar regardless of the country in which the manager is located, then the multinational firm can opt to have the same MCS for the various locales worldwide. This would help in planning, control, and performance evaluation. It would also help with promotion and transfers of personnel from country to country. It would not matter that the Mexican manager wants to transfer to the USA, or that the USA manager could be more effective if transferred to Korea. With only one MCS, the multinational firm can deploy its managers to the location where they can be most effective.

\section{CONCLUSION AND LIMITATIONS}

Today's management must consider global legal, political, economic, and cultural aspects. Each environmental factor is influential to businesses; however, the most difficult to understand and the most often neglected is the influence of culture (Thomas, 2008). This becomes clear when international management is defined by the structure and content of managerial roles as opposed to the function of management. The roles that managers play share certain features across cultures but are best understood in their cultural context. By focusing on these roles, we can understand the importance of interactions between managers and individuals from different cultures. Although politics, economics, and technology can set the standard for international management, it remains a game played through cross-cultural interaction (Thomas, 2008).

Our study provides several contributions. First, in addition to using mid-level managers in a manufacturing setting, our study contributes to cross-cultural studies by using a sample of non-managers to triangulate our results. Thomas (2008) argues that prior literature on cross-cultural studies focus on the organizational context of large firms. Our study uses samples from large and small firms as well as two other non-manager samples in Mexico and Korea. Second, our study uses Mexico, Korea, Hong Kong, and USA to investigate the trend of convergence, if any. Thomas (2008) further argues that most cross-cultural researches focus on a small number of Western European countries, USA, and Japan. There is a knowledge gap about Latin America, Eastern Europe, the Middle East, Africa, and Asia (except for Japan). Our study adds to prior literature by adding samples from neglected locations. Lastly, results of our study do not entirely deny the existence of cultural differences. But our study supports the convergence theory, suggesting that effective management may be largely independent from national culture, and lean naturally towards learning and developing "best" practices throughout the global organization (Carr \& Pudelko, 2006), or structuring systems and operations in similar ways if they are to be efficient and effective (Rungtusanatham, Forza, Koka, Salvador \& Nie, 2005).

\footnotetext{
${ }^{14}$ According to Rugman \& Verbeke (2004), a relatively small set of multinational enterprises (MNEs) account for most of the world's trade and investment. Specifically, the largest 500 MNEs account for over 90 percent of the world's stock of foreign direct investment and they themselves conduct about half the world's trade (Rugman, 2000).
} 
In this study, we observe a trend toward the convergence of cultural values among mid-level managers in four different countries. A surprising finding was the way in which societies handle the problem of accepting hierarchical order and human inequalities (Power Distance as labelled by Hofstede, 1980). Our results show that the cultural value of Power Distance shows signs of convergence, regardless of education and country. In addition, we find that the cultural values of Mexico, Korea, and Hong Kong are similar to those detected in the USA.

From this perspective, our study empirically supports the findings of Ralston, Holt, Terpstra, \& Kai-Cheng (2008). They find that if a multinational is going to become a truly global organization, the diverse individual work values from the various geographic locations of a multinational corporation (MNC) must converge and create a universal corporate culture. The results of our study indicate that global organizations must understand the diverse cultural value systems within their multi-location operations and learn to consolidate these diverse value systems to create their own "universal" corporate culture if they are to create a harmonious organization.

Hofstede (1999) encourages cultural research arguing that organizations aspiring to be global must be cautious when applying the latest management fads and reminds researchers that each culture has its specific set of values. Kirkman et al. (2017) emphasize that "[r]esearchers should not assume that culture equals country," nor assume that culture is static (p. 20). Our results indicate that international business communications and managerial demands are driving cultural values of mid-level managers, and that the cultural values of mid-level managers can be said to be on a convergence course. Our study does not compare Hofstede's data to our sample data, we simply compare his results to our results. In this study we use various sample groups, such as women, men, students, managers, the young and the mature. According to Steel \& Taras (2010), culture scores are influenced by age, gender, education and socioeconomic status of the respondent, suggesting that various sample groups may produce more reliable results compared to a single sample group.

This research suffers from the common limitations all studies have when using a questionnaire to gather the data. Additional limitations include small sample sizes and respondents are mostly males. This last limitation can be explained given that the focus of the study is mid-level manufacturing managers. The Hong Kong sample was obtained at a single car parts manufacturing firm and the average age of respondents in this sample are younger than the samples from the other three geographic areas. The age group of the Hong Kong sample is between 25 to 29 years, whereas the age group of the other countries is between 40 to 49 . Despite these limitations the results add to this literature stream and should allow future researchers to further increase what is known about cultural values and how they can be used to develop hypotheses.

\section{REFERENCES}

Berger, J. \& Heath, C. (2008). Who Drives Divergence? Identify Signaling, Outgroup Dissimilarity, and the Abandonment

Bird, A. \& Stevens, M. (2003). Toward an Emergent Global Culture and the Effects of Globalization on Obsolescing

Boyacigiller, N. \& Adler, N. (1991). The Parochial Dinosaur: Organizational Science in a Global Context. Academy of

Carr, C. \& Pudelko, M. (2006). Convergence of Management Practices in Strategy, Finance and HRM between the USA, Japan and Germany. International Journal of Cross Cultural Management, 6(1), 75-100.

Chung, Y., Hsu, Y. \& Tsai, C. (2010). Research on the Correlation between Implementation Strategies of TQM, Organizational Culture, TQM Activities and Operational Performance in High-Tech Firms. Information Technology Journal, 9(8), 1696-1705.

Cole, R. (1973). Functional Alternatives and Economic Development: An Empirical Example of Permanent Employment in Japan. American Sociological Review, 38(4), 424-438.

Dahlgaard, J. J., Pettersen, J., \& Dahlgaard-Park, S. M. (2011). Quality and Lean Healthcare: A System for Assessing and Improving the Health of Healthcare Organizations. Total Quality Management and Business Excellence, 22(6), 673-689.

De Mooij, M. (2004). Translating Advertising: Painting the Tip of an Iceberg. The Translator, 10(2), 179-198.

Devine, K., O'Clock, P., \& Rooney, C. J. (2000). Implications of Culture on the Development of Control Systems. Ohio CPA Journal, 59(1), 37-41.

DiMaggio, P. (1983). Can Culture Survive the Marketplace? Journal of Arts and Management and Law, 13(1), 61-87.

Dunk, A. (2001). Behavioral Research in Management Accounting: The Past, Present, and Future. Advances in Accounting Behavioral Research, 4, 25-45.

Eisenhardt, S. (1973). Tradition, Change and Modernity. New York, NY: John Wiley \& Sons Publications. 
Evans, R. (1970). Evolution of the Japanese System of Employer-Employee Relations, 1868-1945. Business History Review, 44(1), 110-125.

Gentry, W., \& Sparks, T. (2012). A Convergence/Divergence Perspective of Leadership Competencies Managers Believe are Most Important for Success in Organization: A Cross-Cultural Multilevel Analysis of 40 Countries. Journal of Business and Psychology, 27(1), 15-30.

Green, T. (2012). TQM and Organisational Culture: How Do They Link? Total Quality Management and Business Excellence, 23(2), 141-157.

Harpaz, I. (1990). The Importance of Work Goals: An International Perspective. Journal of International Business Studies, 21(1), 75-93.

Harrison, G. L. (1993). Reliance on Accounting Performance Measures in Superior Evaluative Style - The Influence of National Culture and Personality. Accounting, Organizations and Society, 18(4), 319-339.

Harrison, G. L., \& McKinnon, J. L. (1999). Cross-Cultural Research in Management Control Systems Design: A Review of the Current State. Accounting, Organizations and Society, 24(5-6), 483-506.

Hofstede, G. (1980). Culture's Consequences: International Differences in Work-Related Values. Thousand Oaks, CA: Sage Publications.

Hofstede, G. (1984). Cultural Dimensions in Management and Planning. Asia Pacific Journal of Management, 1(2), 81-99.

Hofstede, G. (1999). Problems Remain, But Theories Will Change: The Universal and the Specific in $21^{\text {st }}$ Century Global Management. Organizational Dynamics, 28(1), 34-45.

Hofstede, G. (2001). Culture's Consequences: Comparing Values, Behaviors, Institutions, and Organizations Across Nations. $2^{\text {nd }}$ ed. Thousand Oaks, CA: Sage Publications, Inc.

Hofstede, G. (2015). Culture's Causes: The Next Challenge. Cross Cultural Management, 22(4), 545-569.

Hofstede, G., \& Bond, M. H. (1988). The Confucius Connection: From Cultural Roots to Economic Growth. Organizational Dynamics, 16(4), 5-21.

Hofstede, G., Hofstede, G. J., \& Minkvov, M. (1991). Cultures and Organizations: Software of the Mind. London, UK: McGraw-Hill.

Hofstede, G., Neuijen, B., Ohayv, D., \&Sanders, G. (1990). Measuring Organizational Cultures: A Qualitative and Quantitative Study across Twenty Cases. Administrative Science Quarterly, 35(2), 286-316.

Hoque, Z. (2014). 20 Years of Studies on the Balanced Scorecard: Trends, Accomplishments, Gaps and Opportunities for Future Research. The British Accounting Review, 46(1), 33-59.

Howes, D. (1996). Cross-Cultural Consumption: Global Markets, Local Realities. New York, NY: Taylor \& Francis Group.

Hui, C. H. (1984). Development and Validation of an Individualism-Collectivism Scale. ONR Number TR-ONR 31. Illinois University at Urbana, Department of Psychology.

Inglehart, R. (2008). Changing Values among Western Publics from 1970 to 2006. Western European Politics, 31(1-2), $130-146$

Inglehart, R., \& Baker, W. E. (2000). Modernization, Cultural change, and the Persistence of Traditional Values. American Sociological Review, 65(1), 19-51.

Kerr, C., Dunlop, J., Harbison, F., \& Myers, C. (1960). Industrialism and Industrial Man: The Problems of Labor and Management in Economic Growth. London, UK: Heinemann.

Kirkman, B. L., Lowe, K. B., \& Gibson, C. B. (2017). A Retrospective on Culture's Consequences: The 35-Year Journey. Journal of International Business Studies, 48(1), 12-29.

Kroeber, A., \& Kluckhohn, F. (1952). Culture: A Critical Review of Concepts and Definitions. Boston: Harvard University Press, Peabody Museum of Archeology and Ethnology 47(1).

Leach-López, M. (2013). Moderating Effect of Hofstede's Cultural Values on the Locus of Control/Job Performance Relationship of Managers in USA, Mexico, South Korea and Hong Kong. Journal of Business Strategies, 30(1), $1-20$.

Leach-López, M., Stammerjohan, S., Lee, E., \& Stammerjohan, C. (2015). Relationship of Budget Participation Conflict and Job Performance of South Korean Managers. Cross-Cultural Management, 22(4), 608-629.

Lee, J. (2015). Korean Women Spent Four Hours per Day to Maintain the Household. Chosun.com, December 7th, 2015 (Printed in Korean). 
Lincoln, J., Olson, J., \& Hanada, M. (1978). Cultural Effects on Organizational Structure: The Case of Japanese Firms in the United States. American Sociological Review, 43(6), 829-847.

Management Review, 16(2), 262-290.

McLeod, D. (2004). Tourism, Globalization and Cultural Change: An Island Community Perspective. New York, NY: Channel View Publication.

Minkov, M., \& Hofstede, G. (2011). The Evolution of Hofstede's Doctrine. Cross Cultural Management, 18(1), 10-20.

Munusamy, V., Valdez, M., Lo, K., Budde-Sung, A., Suarez, C., \& Doktor, R. (2009). Sustained Rapid Economic Growth and Cultural Convergence: Comparative Longitudinal Analysis of Evidence from GLOBE and Hofstede. Journal of Asia Business Studies, 3(2), 37-45.

National Cultures. Journal of International Management, 9(4), 395-407.

Norris, P., \& Inglehart, R. (2009). Is National Diversity Under Threat? Cosmopolitan Communications and Cultural Convergence. Annual Meeting of the American Political Science Association. Toronto.

of Cultural Tastes. Journal of Personality and Social Psychology, 95(3), 593-607.

Perera, M. H. B., \& Mathews, M. R. (1990). The Cultural Relativity of Accounting and International Patterns of Social Accounting. Advances in International Accounting, 3(3), 215-251.

Ralston, D. A., Holt, D. H., Terpstra, R. H., \& Kai-Cheng, Y. (2008). The Impact of National Culture and Economic Ideology on Managerial Work Values: A Study of the United States, Russia, Japan, and China. Journal of International Business Studies, 39(1), 8-26.

Rapp, J., Bernardi, R., \& Bosco, S. (2011). Examining the Use of Hofstede's Uncertainty Avoidance Construct in International Research: A 25-Year Review. International Business Research, 4(1), 3-15.

Ricks, D., Toyne, B., \& Martinez, Z. (1990). Recent Developments in International Management Research. Journal of Management, 16(2), 219-253.

Ritzer, G. (2011). The McDonaldization of Society 6. Newbury Park, CA: Pine Forge Press.

Rowley, C., \& Benson, J. (2002). Convergence and Divergence in Asian Human Resource Management. California Management Review, 44(2), 90-109.

Rugman, A. (2000). The End of Globalization. London, UK: Random House.

Rugman, A., \& Verbeke, A. (2004). A Perspective on Regional and Global Strategies of Multinational Enterprises. Journal of International Business Studies, 35(1), 3-18.

Rungtusanatham, M., Forza, C., Koka, B., Salvador, F., \& Nie, W. (2005). TQM across Multiple Countries: Convergence Hypothesis versus National Specificity Arguments. Journal of Operations Management, 23(1), 43-63.

Salamon, M. (1997). IR: Theory and Practice. London, UK: Prentice Hall.

Salter, S., \& Schulz, A. (2005). Examining the Role of Culture and Acculturation in Information Sharing. Advances in Accounting Behavioral Research, 8, 189-212.

Schwartz, S. (1992). Universals in the Content and Structure of Values: Theoretical Advances and Empirical Tests in 20 Countries. Advanced in Experimental Social Psychology, 25(1), 1-65.

Schwind, H., \& Peterson, R. (1985). Shifting Personal Values in the Japanese Management System. International Studies of Management and Organization, 15(2), 60-74.

Stammerjohan, W., Leach-López, M., \& Stammerjohan, C. (2015). The Moderating Effects of Power Distance on the Budgetary Participation-Performance Relationship. Advances in Management Accounting, 25, 103-148.

Steel, P. \& Taras, V. (2010). Culture as a Consequence: A Multi-level Multivariate Meta- Analysis of the Effects of Individual and Country Characteristics on Work-Related Culture Values. Journal of International Management, 16(3), 211-233.

Tajfel, H. (1982). Social Psychology of Intergroup Relations. Annual Review of Psychology, 33(1), 1-39.

Taras, V., Steel, P., \& Kirkman, B. L. (2012). Improving National Cultural Indices Using a Longitudinal Meta-Analysis of Hofstede's Dimensions. Journal of World Business, 47(3), 329-341.

Thomas, D. (2008). Cross-Cultural Management. Thousand Oaks, CA: Sage Publications.

United States Department of State. (2016a). U.S. Relationship with Mexico. [online] Available at: http://www.state.gov/r/pa/ei/bgn/35749.htm 
United States Department of State. (2016b). U.S. Relationship with South Korea. [online] Available at: http://www.state.gov/r/pa/ei/bgn/2800.htm

United States Department of State. (2016c). U.S. Relationship with Hong Kong. [online] Available at: http://www.state.gov/r/pa/ei/bgn/2747.htm

Vanhala, S., Kaarelson, T., \& Alas, R. (2006). Converging Human Resource Management: A Comparison between Estonian and Finnish HRM. Baltic Journal of Management, 1(1), 82-101.

Verbeke, A., \& Asmussen, C. (2016). Global, Local or Regional? The Locus of MNE Strategies. Journal of Management Studies, 53(6), 1051-1075.

Wang, Z., \& Hunton, J. (2011). The Effect of Congruence between Cultural Time Orientation and Budget Planning Horizon on Employees' Satisfaction with Participative Budgeting. Advances in Accounting Behavior Research, 14, 91116.

Webber, R. (1969). Convergence or Divergence. Columbia Journal of World Business, 4(3), 75-83.

Weed, F. (1979). Industrialization and Welfare Systems: A Critical Evaluation of the Convergence Hypothesis. International Journal of Comparative Sociology, 20(3-4), 282-293.

Westney, D. (1997). Institutionalization Theory and the Multinationals Corporation Culture in S. Ghoshal, E. Westney (Eds), Organization Theory and the Multinational Corporation (53-76). St. Martin's Press, New York, United States.

Yazdifar, H., \& Askarany, D. (2012). A Comparative Study of the Adoption and Implementation of Target Costing in the UK, Australia, and New Zealand. International Journal of Production Economics, 135(1), 382-392. 